\title{
A High School Summer Academy's Effect on Increasing Awareness of the Horticulture Industry and Its Potential to Develop Future Horticulturists
}

\author{
Shelley E. Mitchell and Justin Q. Moss ${ }^{1}$
}

\begin{abstract}
ADDITIONAL INDEX WORDS. horticulture career, horticulture major, recruitment, college, first generation, Oklahoma

SUMMARY. This study examines the impact of a residential horticultural career academy, Camp Tomorrow's Undergraduates Realizing the Future (TURF), conducted from 2010 to 2016 at Oklahoma State University (OSU) in Stillwater, OK. Each year, up to 25 Oklahoma high school students were engaged in 2 weeks of hands-on activities representing a variety of horticulture-related careers. Instructors for Camp TURF included OSU faculty, staff, and graduate students from the Department of Horticulture and Landscape Architecture, related OSU departments, and horticulture and landscape architecture industry professionals. The Oklahoma State Regents for Higher Education sponsored this career academy, which was geared toward potential first-generation college students, and helped to expose students to the university atmosphere as well as expand their knowledge of science- and math-related career fields. Pre- and postassessments given at Camp TURF show significant changes in college readiness and familiarity with horticulture careers, but did not necessarily increase interest in particular horticulture and landscape architecture careers. Upon following up with academy graduates, we learned that the academy has been a positive experience for numerous attendees, with $76.6 \%$ going on to higher education and two students majoring in horticulture and landscape architecture-related areas.
\end{abstract}

$\mathrm{T}$ he U.S. Department of Agriculture reports that job opportunities will grow in the next 5 years for college graduates in the general areas of food, agriculture, renewable natural resources, or environmental fields, with almost 58,000 openings expected per year (Goecker et al., n.d.). Plant scientists, including horticulture-related careers, are anticipated to be in high demand. A rapidly growing world population needs horticulturists to produce more food with fewer resources and to improve the nutritional content of horticultural crops [American Society for Horticultural Science (ASHS), 2014]. However, student populations in horticulture

Department of Horticulture and Landscape Architecture, Oklahoma State University, 358 Agriculture Hall, Stillwater, OK 74078

We thank the Oklahoma State Regents for Higher Education (OSRHE) for funding the summer academy Camp TURF since it began in Summer 2010.

The State Regents are committed to supporting Camp TURF through the Summer 2018. This academy would not be successful without the continued support of the faculty in several departments within the Oklahoma State University College of Agricultural Sciences and Natural Resources, especially the Department of Horticulture and Landscape Architecture.

${ }^{1}$ Corresponding author. E-mail: justin.moss@okstate.edu. doi: 10.21273/HORTTECH03602-16 departments have continued to decrease in the past few decades (Hewett, 2015; Lower, 1991; Palmer, 2004; Rhodus, 1990). Some of the decline is due to common worldwide perceptions that horticulture is primarily manual work, not requiring postsecondary education (Palmer, 2004). In a study of rural youth in Iowa, participants equated "agriculture" with traditional farming and seemed unaware of career opportunities in nontraditional areas of agriculture, such as engineering, genetics, and research (Holz-Clause and Jost, 1995). With seemingly increasing perception issues and decreasing numbers of horticulture students nationwide, the ASHS invited their members to answer an online survey regarding careers in horticulture (Meyer, 2013). The majority of respondents felt that fewer students are majoring in horticulture because they have no awareness of the field. In 2014-15, surveys and face-to-face interviews were conducted with horticulture students and professionals that attended ASHS and American Horticultural Society events, through an online survey of horticulture stakeholders, and through an omnibus phone survey of U.S. adults (Meyer et al., 2016). From the phone survey of U.S. adults, $46 \%$ of respondents answered "did not know" when asked if they agreed or disagreed with the statement that "horticulture is essential to our food, water, and environment." There is a need to educate students and the public about the importance, impact, and potential career opportunities in horticulture. From the online survey of horticulture stakeholders, $31 \%$ of respondents stated that getting handson experience and getting their hands dirty was the most successful method for getting youth interested in horticulture (Meyer et al., 2016). Also, 28\% of respondents stated that providing hands-on opportunities was a way the industry could help motivate high school students to become interested in horticulture.

A good way to increase awareness and interest in different careers is to provide positive experiences for youth (Crombie et al., 2003) since students look to their experiences when developing both educational and occupational plans (Odell, 1988). Rhodus (1990) found that career-influencing events increase enrollment in horticulture programs, even when the increase in enrollment might not be seen for a few years. One way to introduce students to career opportunities in the sciences is to engage them in summer science programs before their college years. Summer science programs increase student interest in science, provide experiences typically not available in most schools, and introduce a variety of science careers. These benefits are especially important to underprivileged students who may not grasp the importance of completing a high school education and going on to attend college (McKendall et al., 2000).

To expose potential students to different career fields in the sciences, science summer academies in a variety of states have focused on agriculture, life sciences, microbiology, immunology, genetics, pharmacy, geosciences, electrical engineering, chemistry, and computer science (Exstrom and Mosher, 2000; Knox et al., 2003; Mehrizi-Sani, 2012; Miller et al., 2007; Moss, 2011; Myers et al., 2012; Pollock et al., 2004; Swortzel et al., 2007). Regardless, there are few university-run summer horticulture opportunities for high school students, and even fewer are reported as studies. 
There is a lack of studies with a large sample size that measure student interest in horticulture and horticultural careers. Evaluation of a 2 -week ornamental horticulture summer program held in Maryland over three summers (from 2005 to 2007) focused on student satisfaction with the program, student knowledge and interest in the areas covered, and the likelihood that the students would pursue an ornamental horticulture career (Marsh et al., 2011). Student perception of their knowledge significantly increased in all areas covered. Student interest increased in the areas of landscape design, turf, horticultural therapy, and tissue culture. Although this study provided a glimpse into the potential of summer academies in horticulture, its sample size of 35 students was small.

Camp TURF is a 2 -week academy designed to raise awareness of and interest in the broad range of horticultural career opportunities. Simultaneously, it must meet the goals of the Oklahoma State Regents for Higher Education (OSRHE) summer academy program, which are to provide stimulating learning opportunities on college campuses, and make success in college an expected and logical result for all participants, particularly those from groups most likely to be underrepresented in fields such as mathematics and science (OSRHE, 2015b). Camp TURF is funded through the OSRHE grant program for mathematics, science, and multidisciplinary studies legislated in 1989 (OSRHE, 2015b). The targeted students for the academy are entering their freshman or sophomore year of high school, as students tend to narrow their lists of potential postsecondary schools by high school (Bradley et al., 2000; Stover, 2007). Camp TURF participants have at least 2 years of high school remainingample time to decide on and change college or career plans.

The main goal of the Camp TURF summer academy was to increase high school student knowledge of and interest in horticulture and landscape architecture. The objective of this study was to determine if the academy affected 1) college readiness, 2) familiarity with horticulture and related careers, or 3 ) stated horticulture career interest. Pre- and postassessments of the Camp TURF summer academy high school participants from 2010 to 2016 were used to measure these objectives.

\section{Materials and methods}

Program marketing. Camp TURF was marketed through the OSRHE website; posters sent to all Oklahoma secondary mathematics and science teachers, school counselors, health departments, and Boys and Girls Clubs; and Oklahoma Cooperative Extension Service educators (those working with youth were sent copies of the camp description and application forms to distribute). All Oklahoma residents of the appropriate grade level were eligible to apply for Camp TURF, which was free to all selected participants.

ACADEMY APPLICATION PROCESS. The one-page application form for Camp TURF requested basic demographic information, high school graduation year, school name and location, teacher's name and contact information, whether the parents have college degrees, and whether the student is part of the Oklahoma Higher Learning Access Program (OHLAP), which is a scholarship program for students whose parents earn less than $\$ 50,000$ per year. Two lines were provided for applicants to list their hobbies and interests and three lines for applicants to answer why they were interested in attending the academy. No letters of recommendation, transcripts, or grade point averages were requested in an effort to keep the application simple and inviting for students of all backgrounds and abilities.

Typically, more applications were received than there were available places for Camp TURF. Students were selected to create a mix of races and ethnicities, with students from lowincome (OHLAP) families and those who will be the first in their families to attend college (first generation) representing the largest group of selected applicants. An effort was made to draw participants from smaller and more rural schools, and to have as many districts as possible represented. Generally, the participants consisted of more female than male students. Very few students listed gardening or horticulture as an interest on their application. Many students stated that they were interested in attending the academy because they wanted to see what college is like, they wanted to meet new potential friends, or they wanted a break from their families. Other summer academies funded by OSRHE are focused on forensic science, mathematics, medicine, field data collection, psychology, engineering, robotics, chemistry, and other science, technology, engineering, and math (STEM) fields. Many academy participants attend two or more different academies in a summer, often choosing an academy due to location (near home or at a college they are interested in visiting) or weeks offered (not conflicting with sports camps or church camps, etc.) as much as the subject matter presented at an academy.

ACAdemy Description. Each academy began with a day at a ropes course to create a cohesive group of students. Attendees spent 2 weeks, including the weekend, living in OSU campus residential suites. During their stay, faculty from the OSU Department of Horticulture and Landscape Architecture, as well as professors from other departments in the OSU College of Agricultural Sciences and Natural Resources, provided hands-on experiences in several areas related to horticulture and landscape architecture.

A variety of OSU faculty, staff, graduate students and industry professionals, both male and female, of varying ages, and of multiple ethnicities, were recruited to demonstrate broad demographics of horticulture and landscape architecture careers. Professionals included sports turf managers, florists, horticulture therapists, arborists, botanic garden managers, owners of landscaping companies and greenhouses, food bank education directors, food cooperative growers, organic farmers, and other horticulture-affiliated professionals. Activities led by faculty varied over the first 7 years of Camp TURF due to student receptiveness and value to the program goals, but typically included a core group of activities related to the areas of college readiness and familiarity with horticulture careers, while trying to pique interest in specific horticulture areas.

Activities addressing college readiness were usually a part of other activities (staying in the residential suites, using departmental classrooms and greenhouses, etc.), and included a talk with admissions counselors, a career interest inventory, and 2 weeks of oncampus residency. Alternative admission methods; various programs on campus available to help freshman and first-generation students succeed both inside and outside of the classroom; and career areas most suited to each student's personality, 
abilities, and achievements were areas of focus.

Activities designed to increase familiarity with horticulture and landscape architecture careers, as well as addressing horticulture career interest, were the main focus of the program, and included both indoor and outdoor experiences. Most activities consisted of one 2- to 4-h session, with the exception of making pervious pavers, which occurred in two 2 -h sessions, $10 \mathrm{~d}$ apart. All activities were mostly hands-on, with minimal lecture, to keep the students engaged and involved. Activities were done individually, in pairs, or in small groups so all students had many active learning experiences. Inside laboratories and greenhouses, students grafted herbaceous plants, created dish gardens with several houseplants, made basic landscape sketches and designs, built model landscapes using chipboard, used micropropagation to clone african violets (Saintpaulia sp.), walked through the processes of soil and water testing, dissected grasshoppers (Romalea sp.), and participated in fun activities such as flower arranging and termite (Reticulitermes flavipes) racing. Outside, students made and tested pervious pavers, identified and measured trees, assembled irrigation systems, identified common turfgrasses and their anatomy, installed and repaired a putting hole in a golf course, and climbed $40 \mathrm{ft}$ up in a sawtooth oak (Quercus acutissima) tree. Students also experienced vertical strawberry (Fragaria sp.) farming, toured a facility that uses hydroponic towers to grow salad greens, learned the basics of organic agriculture from an organic farmer, set up an area for Hugelkultur (garden beds built on top of woody materials such as logs and branches), observed industrial-sized rainwater harvesting, started a bin for vermicomposting, learned about the purpose and functioning of food banks, helped sort produce at a food cooperative, and hosted Oklahoma Gardening education segments on public television (Oklahoma Gardening, 2016). These segments covered topics such as starting softwood cuttings, deadheading, transplanting, dividing ornamental grasses, and making bonsai. Students also worked alongside a horticulture therapist at an assisted living facility, helping elderly residents plant a garden.

Pre- and postassessments. To determine the effects of participation in Camp TURF on college readiness, knowledge of horticulture careers, and interest in horticulture careers, all participants were given identical pre- and postassessments as shown in Table 1. Students took the preassessment before the academy started (anywhere from 1 month before Camp TURF started until upon arrival on campus), and they took the postassessment at the end of the last day of the

Table 1. Sex, race/ethnicity, grade level, school type, participation in the Oklahoma Higher Learning Access Program (OHLAP), and first-generation status of high school participants in Camp Tomorrow's Undergraduates Realizing the Future (TURF) for 2010-16 at Oklahoma State University.

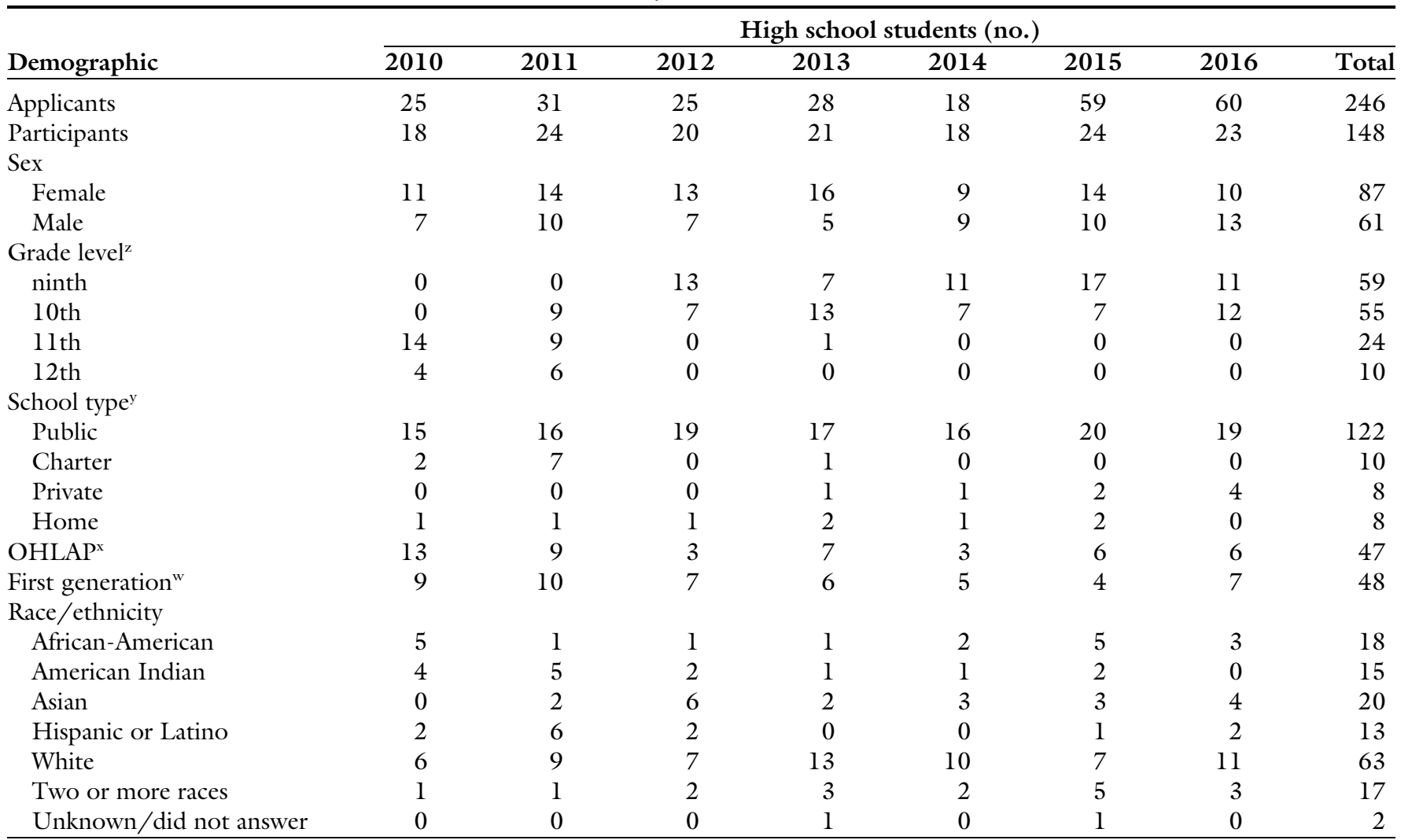

${ }^{\mathrm{z}}$ In 2010 , only high school juniors and seniors were encouraged to apply and participate in Camp TURF. In 2011, only high school sophomores, juniors, and seniors were encouraged to apply and participate in Camp TURF. In 2012-16, only high school freshman and sophomores were encouraged to apply and participate in Camp TURF. ${ }^{y}$ Public represents students that attended State of Oklahoma public schools; Charter represents students that that attended charter schools in Oklahoma; Private represents students that attended non-public, private schools in Oklahoma; and Home represents students that received their schooling at home with parents.

${ }^{x}$ OHLAP is a scholarship program where the State of Oklahoma may provide students from families with an income of $\$ 50,000$ or less a free postsecondary education within the state.

wirst generation was used to denote whether the participant would be the first in their immediate family to attend and graduate with a 4 -year degree from a college or university program. 
academy. A total of 142 of the 148 students participated in the preassessment. Thirty-four of the students decided not to participate in the postassessment $(\mathrm{N}=114)$. The preand postassessments contained 19 statements related to three areas: statements 1-7 related to career readiness, 8-13 related to knowledge of horticulture careers, and 14-19 related to interest in horticultural careers. The assessment instructed students to circle their level of agreement for each statement on a 5-point Likert-type scale where $1=$ strongly disagree, $2=$ disagree, $3=$ neutral, $4=$ agree, and $5=$ strongly agree.

Quantitative data were analyzed with SAS (version 9.4; SAS Institute, Cary, NC) using PROC CORR, PROC FACTOR, and PROC GLM. Analysis of variance for pre- and postassessment data were analyzed at the 0.05 significance level both in aggregate and by year of participation. Since the pre- and postsurveys were conducted to maintain the anonymity of the respondents, we were not able to conduct an analysis of variance or analyze responses by sex, grade level, race/ethnicity, or other factors. Survey reliability was determined by calculating Cronbach's alpha (internal consistency) of the pre- and postassessment. Cronbach's alpha was 0.9 for the preassessment and 0.77 for the postassessment. Qualitative data were collected from written and oral responses of participants, both during the academy (comments stated by participants during activities) and after the academy, through emails and social media posts by the attendees and their parents.

Follow-Up. The OSRHE maintains a database of all summer academy participants and keeps track of their college or university enrollment, major, and year, as long as they stay in Oklahoma. For the participants who moved out of state, we used personal communication via e-mail or social media to gather their higher education progress and other qualitative data. Only students who had graduated high school at the time of writing this manuscript $(\mathrm{N}=47)$ were included in the follow-up.

\section{Results and discussion}

In the first 7 years of Camp TURF, students came from 32 of the 77 counties in Oklahoma. Males represented $41.2 \%$ of the 148 participants, with females making up $58.8 \%$ (Table 1). The students self-reported as White $(42.6 \%)$, Asian (13.5\%), AfricanAmerican (12.2\%), multiracial (11.5\%), American Indian (10.1\%), and Hispanic or Latino (8.8\%). Forty-seven students (31.8\% of the participants) were part of OHLAP (signifying those from lowerincome families), and 48 (32.4\%) were upcoming first-generation college students. The first year of Camp TURF, only rising juniors and seniors were invited to apply, because of departmental administrative pressure to immediately increase enrollment in horticulture. However, due to behavioral issues and the realization that juniors and seniors had already decided upon a career path, students entering ninth and 10th grades became the focus of the academy. Participants came primarily from public schools $(82.4 \%)$, with students also representing charter schools (6.7\%), private schools $(5.4 \%)$, and homeschools (5.4\%).

The assessment statement means through all 7 years on the pre- and postassessments are summarized in Table 2. There were no significant differences among responses between years, allowing us to pool the data over years. Statistically significant differences

Table 2. Pre- and postsurvey statements and results for Oklahoma State University's Camp Tomorrow's Undergraduates Realizing the Future (TURF) high school participants from 2010 to $2016 .{ }^{\mathrm{z}}$

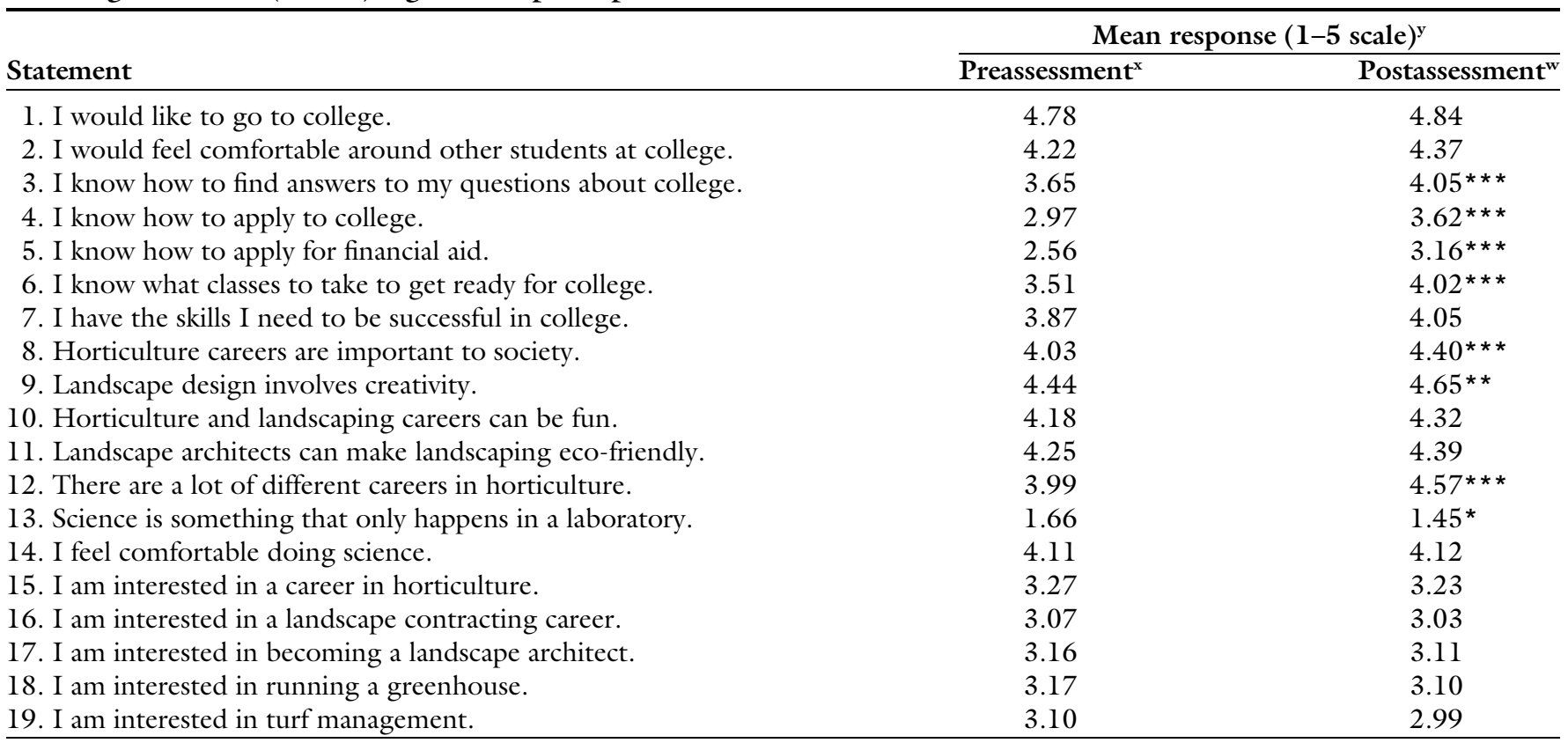

${ }^{\mathrm{z} D}$ Directions at the top of the pre- and postsurvey instruments stated: "Please help us evaluate our academy's performance. The questions below are designed to measure your knowledge, attitude, and skills both before and after the academy. This is not a test to evaluate you; this is to test ourselves on how good a job we are doing teaching you different concepts and skills. Thank you for your help! Please circle the choice that most closely matches your response for each statement."

${ }^{{ }^{y}}$ The survey responses were collected and interpreted using a Likert-type scale where $1=$ strongly disagree, $2=$ disagree, $3=$ neutral, $4=$ agree, and $5=$ strongly agree.

${ }^{\mathrm{x}} \mathrm{N}=142$ responses.

${ }^{\mathrm{w}} \mathrm{N}=114$ responses.

$*, * *, * *$ Significant at $P \leq 0.05,0.01$, and 0.001 , respectively. 
are noted on eight of the 19 survey statements. Perception of knowledge about college preparation significantly increased in the areas of finding answers to questions about college [Statement 3 (S3)], the application process (S4), applying for financial aid (S5), and college-preparatory classes in high school (S6). This is similar to what a health sciences and technology academy discovered; those participants felt more prepared for college (on average, $0.33 \%$ re) as a result of the academy (McKendall et al., 2000).

A significant gain was made in the knowledge that there are many different careers in the horticulture field (S12). Unsolicited participant comments support the findings: "I learned about many new careers" (2011 participant, unpublished data), "You introduced me to a whole new world. Before the camp I had no interest in plants. Now I see it's just not about plants, but a whole lot more" (2011 participant, unpublished data), and "I have learned so much about agriculture and have decided to become an agriculture engineer, and plan to come up to OSU for colledge [sic]!" (2011 participant, unpublished data). One of the goals of the Camp TURF academy was to make students aware of the variety of careers available in the horticulture and landscaping fields, and that goal was met, as significantly more respondents knew about a wide variety of careers in the postsurvey. We observed three other areas of significant gain based on the pre- and postassessments: horticulture careers are important to society (S8), landscape design is a creative field (S9), and science does not strictly happen in the confines of a laboratory space (S13).

There was no significant change in interest in horticulture careers including specific interest in landscape contracting, landscape architecture, greenhouse management, and turfgrass management. The researchers expected the camp activities, most of which were enjoyed by nearly all students (judging by student's qualitative comments during and after the activities), to increase interest (Crombie et al., 2003). However, the insignificant changes in career interest are consistent with the study by Bhattacharyya et al. (2011) that showed interest in science careers was not significantly changed despite a positive change in student's perception of science. Camp TURF occurs during one of the hottest months (June) of the year in Oklahoma, and many of the activities occur outdoors, which may contribute to an unenthusiastic response in career interest. Another possible reason for lack of interest in horticulture as a career is the low pay: the U.S. Bureau of Labor Statistics' (BLS) Occupational Outlook Handbook shows "grounds maintenance workers" earning a median income in 2015 of $\$ 25,610$ (BLS, 2015a) and "agricultural workers" earning a median income of $\$ 20,090$ (BLS, 2015b), neither of which requires a college education. In the same year, the handbook shows "agricultural and food scientists" with a bachelor's degree earning a median income of $\$ 62,470$ (BLS, 2015c) and "landscape architects" with a bachelor's degree earning a median income of $\$ 63,810$ (BLS, 2015d). A survey of graduates with bachelor's degrees in 319 fields from 1,063 universities yielded a list of the " 30 Worst Paying College Majors for 2016"; horticulture was number 26 on the list, with a starting salary of $\$ 35,400$ and a midcareer salary of $\$ 49,400$ (Berman, 2016).

Another challenge with Camp TURF, and similarly with other summer academies, is that since it is free to attend (to make sure all students are able to afford it), there are some students who fail to attend each year (there are no penalties for not canceling in advance). In visiting with a school counselor from an area with several nonattendees 1 year, it was suggested that the parents of some students persuade the students to stay home from the academy, because they do not want their children to get excited about college and leave their family and/or hometown. While the students who do come represent families with no apparent dislike for college attendance, not all of them come from families with college graduates. Indeed, a main goal of Camp TURF was to get first-generation students convinced that college is within their means, specifically in horticulture at OSU.

Camp TURF participants now have personal experiences from which to draw when making decisions about their potential interest in horticulture, landscape contracting/management, or landscape architecture careers, having spent 2 weeks engaged in a variety of activities representing many facets of those areas. The academy helped at least some of the participants feel at ease regarding college attendance, daily school activities, and leaving their familiar home surroundings. Thirty-six of the 47 Camp TURF participants who have since graduated from high school (as of 2015) have attended college $(76.6 \%)$, with at least half of those majoring in a science field (one in Applied Plant Sciences), and one majoring in Landscape Architecture; it appears that these students felt comfortable enough to attend college and even venture into horticulture fields.

Camp TURF's current college attendance rate is $76.6 \%, 20.6 \%$ higher than Oklahoma's state average (56\%) among high school graduates (OSRHE, 2015a). This is similar to the results of a science agricultural summer experience in New Mexico, where 86\% of their academy attendees continued on to college, which is higher than the northern New Mexico average at 25\% (Martinez et al., 2012). Seven previous Camp TURF attendees have matriculated at OSU, with one majoring in landscape architecture, stating that she made her decision to become a landscape architect while doing related activities at Camp TURF.

Hopefully, more Camp TURF students will choose to enter the horticulture field, helping to close the employment gap that currently exists worldwide. As a way to keep horticulture in the participants' minds while preparing for college and to attract future students to the department, starting in 2015 all Camp TURF participants are given a $\$ 500$ departmental scholarship valid until their college sophomore year providing they choose to major in horticulture, landscape management, or landscape architecture. Based on the current results, the TURF academy has potential to provide high school students with a positive experience that can potentially result in their choice of horticulture as a major, but overall positive results may not pay off for several years. If other university programs create similar experiences, it is suggested that a long-term investment is initiated with a robust plan for appropriate assessment of student success, major, and career choice. 


\section{Literature cited}

American Society for Horticultural Science. 2014. Promoting horticulture in the United States. 4 Mar. 2016. <http:// www.ashs.org/resource/resmgr/Docs/ WhitePaper-PromotingUS-Horti.pdf>.

Berman, D. 2016. 30 worst paying college majors: 2016. 11 May 2016. <http:// www.thinkadvisor.com/2016/05/11/ 30 -worst-paying-college-majors-2016? page_all $=1$ \&slreturn $=1479758578>$.

Bhattacharyya, S., R. Nathaniel, and T.P. Mead. 2011. The influence of science summer camp on African-American high school students' career choices. School Sci. Mathematics Assn. 111:345-353.

Bradley, J.C., T. Kohlleppel, T.M. Waliczek, and J.M. Zajicek. 2000. Factors affecting recruitment of horticulture students at major universities. HortTechnology 10:631-636.

Crombie, G., J.P. Walsh, and A. Trinneer. 2003. Positive effects of science and technology summer camps on confidence, values, and future intentions. Can. J. Counsell. 37:256-269.

Exstrom, C.L. and M.D. Mosher. 2000. A novel high school chemistry camp as an outreach model for regional colleges and universities. J. Chem. Educ. 77:1295-1297.

Goecker, A.D., E. Smith, J.M. Fernandez, R. Ali, and R.G. Theller. (n.d.). Employment opportunities for college graduates in food, agriculture, renewable natural resources, and the environment. USDA. 8 Mar. 2016. <https://www.purdue. edu/usda/employment/ $>$.

Hewett, E.W. 2015. Is horticultural science in crisis? What is needed to assure its future? 8 Mar. 2016. <http://www.ishs. org/news/horticultural-science-crisiswhat-needed-assure-its-future $>$.

Holz-Clause, M. and M. Jost. 1995. Using focus groups to check youth perceptions of agriculture. J. Ext. 33(3). 4 Feb. 2016. <http://www.joe.org/joe/1995june/a3. php>.

Knox, K.L., J.A. Moynihan, and D.G. Markowitz. 2003. Evaluation of shortterm impact of a high school summer science program on students' perceived knowledge and skills. J. Sci. Educ. Technol. 12:471-478.

Lower, R.L. 1991. Horticulture at risk: Presidential address. HortScience 26:1447-1449.
Marsh, L.E., C.P. Cotton, F.M. Hashem, and R.B. Dadson. 2011. An ornamental summer program for high school students: Issues and perspectives. J. North Amer. Colleges Teachers Agr. 55:8-13.

Martinez, E., J. Lindline, M.S. Petronis, and M. Pilotti. 2012. Effectiveness of a science agricultural summer experience (SASE) in recruiting students to natural resources management. J. Sci. Educ. Technol. 21:713-721.

McKendall, S.B., P. Simoyi, A.L. Chester, and J.A. Rye. 2000. The Health Sciences and Technology Academy: Utilizing pre-college enrichment programming to minimize post-secondary education barriers for underserved youth. Acad. Med. 75:S121-S123.

Mehrizi-Sani, A. 2012. Everyday electrical engineering: A one-week summer academy course for high school students. Inst. Electrical Electronics Eng. Trans. Educ. 55:488-494.

Meyer, M.H. 2013. Horticulture career survey: What you said. ASHS Nwsl. 29(9):3-4.

Meyer, M.H., D. Needham, J. Dole, B. Trader, J. Fox, M. Conley, M. Neff, and J. Shaw. 2016. Importance of horticulture and perception as a career. HortTechnology 26:114-120.

Miller, K.C., T. Carrick, C. MartinezSussmann, R. Levine, C.L. Andronicos, and R.P. Langford. 2007. Effectiveness of a summer experience for inspiring interest in geoscience among Hispanic-American high school students. J. Geosci. Educ. 55:596-603.

Moss, J.Q. 2011. An undergraduate summer research and mentorship experience for underrepresented students in the agricultural sciences. J. North Amer. Colleges Teachers Agr. 55:32-37.

Myers, T.L., R.M. DeHart, E.B. Dunn, and S.F. Gardner. 2012. A summer pharmacy camp for high school students as a pharmacy student recruitment tool. Amer. J. Pharm. Educ. 76(4):1-6.

Odell, K.S. 1988. The educational and occupational expectations of rural Ohio tenth- and twelfth-grade students. Res. Rural Educ. 5(2):17-21.

Oklahoma Gardening. 2016. Oklahoma Gardening YouTube channel: Camp TURF segments. 6 Dec. 2016. <https://www. youtube.com/user/OklahomaGardening/ search?query $=$ camp+turf $>$.
Oklahoma State Regents for Higher Education. 2015a. Degrees of progress: The state of higher education in Oklahoma. 4 Mar. 2016. <http://www.okhighered. org/studies-reports/annual-report/annualreport2014.pdfs.

Oklahoma State Regents for Higher Education. 2015b. Request for proposals (RFP) FY2016: Guidelines and procedures for summer academies for mathematics, science, and multidisciplinary studies. 9 Sept. 2015. <http://www. okhighered.org/grant-opps/osrhe-grants. shtml>.

Palmer, J. 2004. Does horticultural science have a future? 26 Nov. 2008. <http:// www.ishs.org/future/intr_txtl.htm>.

Pollock, L., K. McCoy, S. Carberry, N. Hundigopal, and X. You. 2004. Increasing high school girls' self-confidence and awareness of CS through a positive summer experience. Assn. Computer Machinery Spec. Interest Group Computer Sci. Educ. Bul. 36(1):185-189.

Rhodus, W.T. 1990. Analysis of recent enrollment trends and recruiting strategies in horticulture. HortScience 25:14431446.

Stover, C. 2007. Engaging high school sophomores. Recruitment Retention Higher Ed. 21(12):1-2.

Swortzel, K.A., J.P. Deeds, and W.N. Taylor. 2007. Recruiting students for agricultural careers through CSI: Agriculture. Proc. 2007 Amer. Assn. Agr. Educ. Res. Conf. 34:754-756.

U.S. Bureau of Labor Statistics. 2015a. Grounds maintenance workers. 17 Dec. 2015. <http://www.bls.gov/ooh/buildingand-grounds-cleaning/grounds-maintenanceworkers.htm>.

U.S. Bureau of Labor Statistics. 2015b. Agricultural workers. 17 Dec. 2015. <http:// www.bls.gov/ooh/farming-fishing-andforestry/agricultural-workers.htm>.

U.S. Bureau of Labor Statistics. 2015c. Agricultural and food scientists. 17 Dec. 2015. <http://www.bls.gov/ooh/lifephysical-and-social-science/agriculturaland-food-scientists.htm>.

U.S. Bureau of Labor Statistics. 2015d. Landscape architects. 17 Dec. 2015. <http:// www.bls.gov/ooh/architecture-andengineering/landscape-architects.htm>. 